\title{
Qualitative studies of obesity: A review of methodology
}

\author{
Ian Brown*, Jill Gould
}

Centre for Health \& Social Care Research, Sheffield Hallam University, Sheffield, UK;

*Corresponding Author: ian.brown@shu.ac.uk

Received 25 June 2013; revised 25 July 2013; accepted 10 August 2013

Copyright (c) 2013 Ian Brown, Jill Gould. This is an open access article distributed under the Creative Commons Attribution License, which permits unrestricted use, distribution, and reproduction in any medium, provided the original work is properly cited.

\begin{abstract}
BACKGROUND: There is a developing interest in qualitative research to understand the perspectives and experiences of people living with obesity. However, obesity is a stigmatised condition associated with negative stereotypes. Social contexts emphasizing large body size as a problem, including research interviews, may amplify obesity stigma. This study reviews the methodology employed by qualitative studies in which study participants were obese and data collection involved face-to-face interviews. METHODS: Database searches identified qualitative studies meeting inclusion criteria from 1995 to 2012. Following screening and appraisal data were systematically extracted and analyzed from 31 studies. RESULTS: The studies included 1206 participants with a mean age of 44 years and mean BMI of $37 \mathrm{~kg} / \mathrm{m}^{2}$. Women (78.8\%) outnumbered men (21.2\%) by four to one. Socio-economic background was not consistently reported. The studies employed similar, typically pragmatic, qualitative methodologies, providing rich textual data on the experience of obesity derived from face-to-face interviews. The majority considered quality issues in data collection, analyses and generalizability of findings. However, the studies were weak as regards researcher reflexivity in relation to interviewer characteristics and obesity stigma. CONCLUSIONS: The impact of obesity stigma has not been attended to in the qualitative research. Clear information about study participants is essential, but studies involving face-to-face interviews should also report on interviewer characteristics including body size.
\end{abstract}

Keywords: Obesity; Stigma; Qualitative Methods; Researcher Reflexivity

\section{INTRODUCTION}

Qualitative studies have become an accepted methodology within health research [1-2]. Advocates note the strength of qualitative methods in delivering a greater depth of understanding of, for example, the complex phenomena faced by patients living with long term conditions [3-4]. Appreciation of the methods, quality criteria and reporting standards needed for rigorous qualitative research has also become established; and a number of excellent checklists and guides are available [5-7]. Systematic reviews and syntheses of qualitative studies are recognized as a useful contribution to evidence and policy development [8-9].

Core definitions of qualitative research point up the value of flexibility within an emergent design in which textual data are acquired to explore social phenomena in context [10]. In practice, in health and medical research, the data are typically gathered from individual or group interviews or, less frequently, from observation of interactions such as between patient and clinician within a consultation. Analyses typically proceed through iterative stages of coding data to inductively develop, for example, themes, frameworks and theories [11].

Building on previous guidelines and an extensive literature review, the COREQ checklist is useful for studies employing interviews and focus groups [7]. Criteria are grouped within three domains. In the first, labeled "research team and reflexivity", attention is drawn to how characteristics of the research team and relationships with participants affect responses, interpretation of data and hence credibility of findings. The second domain highlights how the study's theoretical framework (methodology), sampling, setting, data collection methods affect study quality and findings. The third domain focuses 
on data analysis, interpretation and reporting.

Obesity is viewed as a long term medical condition and is currently one of great concern for public health because of obesity's increasing prevalence and the associated risks for diabetes and other chronic diseases [1214]. There has been growing interest in the perspectives and experiences of patients living with obesity and a developing appreciation of the degree to which obesity is a stigmatized condition, associated with negative attitudes and discrimination in many countries [15,16]. People who are obese face difficulties in various spheres of life, such as in education and employment. Derogatory portrayals of obesity are common within the culture and media of these societies.

Stigma is the phenomenon in which societal evaluations negatively impact on individuals' sense of identity and self-presentation [15]. In some societies, obesity brings a strongly devalued physical and moral identity, creating challenges for those affected by obesity in managing their identity and in presenting themselves in social interaction. Obesity stigma has general consequences in many spheres of life for affected individuals. However, interactions oriented to obesity and therefore emphasizing large body size as a problem, are a context in which stigma will be amplified [16]. This has important, but uncharted, consequences for research about obesity, particularly, research involving face-to-face interaction in data collection.

In this paper, we report on a literature review of qualitative studies in which the study participants were adults categorized as obese and the data collection involved face-to-face methods.

\section{METHODS}

\subsection{Design and Searches}

We employed established methods in searches, appraisal, data extraction and analysis of relevant literature [17-19]. We eventually included 31 qualitative studies of obesity in which all, or the great majority, of participants were obese and data collection employed face-to-face methods. The studies were drawn from a range of disciplines after electronic, lateral and key journal searches covering the period January 1995 to July 2012. The databases included: AMED (Ovid); CENTRAL (Cochrane Library); CINAHL (Ebsco); Medline (Ebsco); PsychINFO (CSA); SCOPUS; Web of Science (ISI Web of Knowledge).

Search terms were employed to identify all studies reporting findings on experiences of obesity derived from inductive analysis of qualitative data. An illustrative search in CINAHL with search terms is shown in Table 1. We used search and screening tools within each database
Table 1. Illustrative search (CINAHL).

\begin{tabular}{ccc}
\hline$\#$ & \multicolumn{1}{c}{ Query } & Results \\
\hline S4 & \multicolumn{1}{c}{ S1 and S2 and S3 } & 381 \\
S3 & MW qualitative studies or AB qualitative & 46615 \\
& & \\
& $\begin{array}{l}\text { MW ( weight loss OR weight control OR obesity OR } \\
\text { overweight OR body mass index ) or AB (obes }{ }^{*} \text { OR } \\
\text { overweight OR BMI OR "body mass index" OR }\end{array}$ & \\
weight N3 los ${ }^{*}$ OR weight N3 control & \\
&
\end{tabular}

to include synonyms, word variants, database labels and to remove duplicates and exclude studies not meeting our criteria. Only English language studies were included.

\subsection{Exclusions and Analyses}

After independently screening of 417 study abstracts, we were able to exclude the majority (356) because they were not a qualitative study involving adult participants.

We appraised the full report of 61 studies and excluded 30 studies for the following main reasons: nine did not provide sufficient information about how data were collected and analyzed or about participant characteristics to be sure participants were mainly obese; seven the sample majority were normal weight or underweight; five the focus was not obesity with inductive analysis of qualitative data; five did not use face-to-face data collection methods; three the sample were not adults; and in one duplicate findings were reported in more detail in an included study.

Methodology information was systematically extracted from the 31 included study reports and summarized in matrices for analysis. Both authors checked extracted data against the original study report. Both authors worked initially independently to identify and then agree on key themes and issues from the extracted data.

\section{RESULTS}

Included studies are summarized within Table 2 [2052]. Typically these studies aimed to explore and describe adults' perceptions and experiences of obesity and of weight management interventions. Our present focus is on the methodology of the reviewed studies not their 
Table 2. Summary of reviewed studies.

\begin{tabular}{|c|c|c|c|c|c|c|}
\hline \multirow{2}{*}{$\begin{array}{l}\text { Authors } \\
\text { (Country) } \\
\text { Study aims }\end{array}$} & \multirow{2}{*}{$\begin{array}{l}\text { Context and } \\
\text { recruitment }\end{array}$} & \multirow[b]{2}{*}{ Participants } & \multicolumn{3}{|c|}{ Methodology } & \multirow{2}{*}{$\begin{array}{l}\text { Limitations } \\
\text { discussed } \\
\text { by authors }\end{array}$} \\
\hline & & & Data collection & Approach & $\begin{array}{l}\text { Interviewer } \\
\text { Characteristics }\end{array}$ & \\
\hline $\begin{array}{l}\text { Ali, et al. } 2010 \text { (UAE) } \\
\text { To explore barriers and } \\
\text { enablers to weight } \\
\text { management of } \\
\text { women at high risk of } \\
\text { Type } 2 \text { diabetes }\end{array}$ & $\begin{array}{l}\text { Mix urban, suburban } \\
\text { and semi-rural; } \\
\text { Primary care centres } \\
\text { in one region of } \\
\text { UAE. Doctors in the } \\
\text { selected health } \\
\text { centres invited } \\
\text { participants }\end{array}$ & $\begin{array}{c}75 \text { participants } \\
\text { Mean age } 39.1 \\
\text { years } 30.7 \% \\
\text { overweight } \\
44.0 \% \text { obese } \\
\text { Women } 100 \%\end{array}$ & $\begin{array}{l}\text { Eight focus } \\
\text { groups. } \\
\text { audio recording } \\
\\
\text { Height, weight } \\
\text { and waist } \\
\text { circumference } \\
\text { measured prior to } \\
\text { focus group }\end{array}$ & $\begin{array}{l}\text { Influence of } \\
\text { grounded theory } \\
\text { approach and } \\
\text { constant } \\
\text { comparative } \\
\text { methods }\end{array}$ & $\begin{array}{l}\text { Two female Emirati } \\
\text { nurses trained in focus } \\
\text { group facilitation. } \\
\text { No mention of age or } \\
\text { body size. }\end{array}$ & $\begin{array}{l}\text { Sampling and } \\
\text { generalisability }\end{array}$ \\
\hline $\begin{array}{c}\text { Befort, et al. } 2008 \\
\text { (USA) } \\
\text { To explore perceptions } \\
\text { and beliefs related to } \\
\text { body size, weight, and } \\
\text { weight loss }\end{array}$ & $\begin{array}{l}\text { Predominantly low } \\
\text { income, urban; USA } \\
\text { mid-west state } \\
\text { various community } \\
\text { settings Recruited } \\
\text { with flyers posted } \\
\text { throughout the } \\
\text { community }\end{array}$ & $\begin{array}{c}62 \\
\text { Afrcan-American } \\
\text { women } \\
\text { Mean age 46.6 } \\
\text { Mean BMI } \\
40.3 . \\
75.8 \% \\
\text { co-morbidity } \\
\text { Women } 100 \%\end{array}$ & $\begin{array}{l}\text { Height and weight } \\
\text { measured after the } \\
\text { focus group }\end{array}$ & $\begin{array}{l}\text { A grounded } \\
\text { theory approach. } \\
\text { Cross checking } \\
\text { of analysis and } \\
\text { team discussion } \\
\text { to arrive at } \\
\text { themes }\end{array}$ & $\begin{array}{l}\text { Focus groups moderated } \\
\text { by two clinical } \\
\text { psychologists with } \\
\text { training in group } \\
\text { facilitation. Two } \\
\text { research assistants. } \\
\text { No mention of gender, } \\
\text { age, ethnicity or body } \\
\text { size. Research assistant } \\
\text { identified as female } \\
\text { African American. }\end{array}$ & $\begin{array}{l}\text { Sampling and } \\
\text { generalisability }\end{array}$ \\
\hline $\begin{array}{l}\text { Blixen, et al. } 2006 \\
\text { (USA) } \\
\text { To identify differences } \\
\text { in values and beliefs } \\
\text { about obesity and } \\
\text { weight reduction, } \\
\text { knowledge of obesity } \\
\text { related medical } \\
\text { conditions, and } \\
\text { self-perceived barriers } \\
\text { to weight loss between } \\
\text { African American } \\
\text { (AA) and Caucasian } \\
\text { (C) women }\end{array}$ & $\begin{array}{l}\text { No indication of } \\
\text { socio-economic } \\
\text { status; Recruitment } \\
\text { of African American } \\
\text { and Caucasian } \\
\text { women from hospital } \\
\text { medical outpatients } \\
\text { in Midwest US }\end{array}$ & $\begin{array}{l}20 \text { participants } \\
\text { BMI > 30. } \\
\text { Mean age-- } \\
\text { AA group 39.3; } \\
\text { C group } 46.2 \\
\text { Women } 100 \%\end{array}$ & $\begin{array}{l}\text { Four focus groups } \\
\text { audio recording. } \\
\text { Groups stratified } \\
\text { to AA and C } \\
\text { women. }\end{array}$ & $\begin{array}{l}\text { Grounded } \\
\text { theory- } \\
\text { constant } \\
\text { comparative } \\
\text { method of } \\
\text { analysis used to } \\
\text { generate } \\
\text { constructs } \\
\text { based on coded } \\
\text { themes. }\end{array}$ & $\begin{array}{l}\text { “Discussion was } \\
\text { conducted by a } \\
\text { moderator...”. } \\
\text { No mention of gender; } \\
\text { age, ethnicity or body } \\
\text { size of moderator. }\end{array}$ & $\begin{array}{l}\text { Potential biases } \\
\text { arising from the } \\
\text { influence of } \\
\text { group dynamics. }\end{array}$ \\
\hline $\begin{array}{l}\text { Brown, Jones, et al. } \\
\text { 2006a (UK) } \\
\text { To develop a } \\
\text { theoretical model of } \\
\text { the links between } \\
\text { obesity and quality } \\
\text { of life }\end{array}$ & $\begin{array}{l}\text { Predominantly } \\
\text { urban, (industrial } \\
\text { city, north of } \\
\text { England) } \\
\text { Recruited from } \\
\text { general practice } \\
\text { Diverse/contrasting } \\
\text { socio-economic } \\
\text { population }\end{array}$ & $\begin{array}{c}28 \text { participants } \\
\text { Mean age } 56 \\
\text { years; } \\
\text { Mean BMI } \\
35.6 \\
\text { 86\% at least } \\
\text { one } \\
\text { co-morbidity } \\
\text { Women 64\% } \\
(n=18) \\
\text { Men 36\% } \\
(n=10)\end{array}$ & $\begin{array}{l}28 \text { individual } \\
\text { interviews (face } \\
\text { to face in the } \\
\text { patient’s home) } \\
\\
\text { Recruited patients } \\
\text { with a recorded } \\
\text { diagnosis of } \\
\text { obesity from GP } \\
\text { surgeries }\end{array}$ & $\begin{array}{l}\text { Grounded theory } \\
\text { approach }\end{array}$ & $\begin{array}{l}\text { No mention of gender; } \\
\text { age, ethnicity or body } \\
\text { size of interviewers. } \\
\text { NOTE: Research team } \\
\text { included patient } \\
\text { representatives with } \\
\text { personal experience } \\
\text { of obesity. }\end{array}$ & $\begin{array}{c}\text { Generalisability } \\
\text { but } \\
\text { argues } \\
\text { purpose was to } \\
\text { generate theory. }\end{array}$ \\
\hline $\begin{array}{l}\text { Brown, et al. 2006a } \\
\text { (UK) } \\
\text { To explore perceptions } \\
\text { and experiences of } \\
\text { patients diagnosed as } \\
\text { obese }\end{array}$ & $\begin{array}{l}\text { Predominantly } \\
\text { urban, (industrial } \\
\text { city, north of } \\
\text { England); Recruited } \\
\text { from general practice } \\
\text { Diverse/contrasting } \\
\text { socio-economic } \\
\text { population }\end{array}$ & $\begin{array}{c}28 \text { participants } \\
\text { Mean age } 56 \\
\text { years; } \\
\text { Mean BMI } \\
35.6 \\
86 \% \text { at least } \\
\text { one } \\
\text { co-morbidity } \\
\text { Women } 64 \% \\
(n=18) \\
\text { Men } 36 \% \\
(n=10)\end{array}$ & $\begin{array}{l}28 \text { individual } \\
\text { interviews } \\
\text { (Recruitment/ } \\
\text { sample as above) }\end{array}$ & $\begin{array}{l}\text { Grounded theory } \\
\text { approach }\end{array}$ & $\begin{array}{l}\text { No mention of gender; } \\
\text { age, ethnicity or body } \\
\text { size of interviewers. } \\
\text { NOTE: Research team } \\
\text { included patient } \\
\text { representatives with } \\
\text { personal experience } \\
\text { of obesity. }\end{array}$ & $\begin{array}{c}\text { Recruitment } \\
\text { bias-difficult } \\
\text { to assess. } \\
\text { Sample did not } \\
\text { include Black } \\
\text { and Asian ethnic } \\
\text { minority groups } \\
\text { although present } \\
\text { in the } \\
\text { population. }\end{array}$ \\
\hline
\end{tabular}




\section{Continued}

\begin{tabular}{|c|}
\hline $\begin{array}{c}\text { Byrne, et al. } 2003 \\
\text { (UK) } \\
\text { To investigate } \\
\text { psychological } \\
\text { factors associated } \\
\text { with weight } \\
\text { maintenance } \\
\text { and relapse } \\
\text { in obesity }\end{array}$ \\
\hline $\begin{array}{l}\text { Chan and Gillick } \\
\text { 2009 (USA) } \\
\text { To explore } \\
\text { construction of } \\
\text { identities in } \\
\text { relation to } \\
\text { fatness and } \\
\text { disability }\end{array}$ \\
\hline
\end{tabular}

Chang et al. 2009

\section{(Malaysia)}

To explore the perceptions of,

feelings and attitudes toward overweight or obesity and the perceived barriers to weight loss among native adults from lower socio-economic background

\section{da Silva et al. 2012 (Portugal) To explore expectations and beliefs about obesity and obesity treatment, particularly bariatric surgery}

\section{Diaz et al. 2007} (USA)

To describe the weight loss experiences, attitudes and barriers in Latino adults

\section{Granberg 2006} (USA)

To examine how individuals who lose significant weight negotiate this challenge to self and identity
Chicago USA. Participants recruited from community and medical centres in urban Chicago

\section{Participants: 76}

Mean age 41

UK-mixed socio-economic

Participants

recruited by

newspaper

adverts
56 with history or

current obesity: 28

"Maintainers"; 28

"Regainers"; 20

healthy weight for comparison.

Women 100\% $(n=76)$

\section{0 individual interviews \\ Two group interviews. \\ No mention of \\ measurement \\ No broad approach specified \\ Transcript data coded into grouped themes or topics}

7 individual interviews.

\section{7 participants}

mean age 47.6 years mean BMI 43.3 Women 43\% $(n=3)$

Men 57\% $(n=4)$
No broad approach specified

Transcript data coded into concepts and themes
BMI as a selection parameter for recuitment
No mention of gender; age, ethnicity or body size of interviewers or group facilitators.

"Researchers identify with both the fat and disability communities; particularly sensitive to the issues facing marginalized groups. The commonalities between the researchers and participants gave way to a comfortable, free sharing atmosphere which enhanced the quality of the data.”
Rural region of Malaysia Recruitment was by an announcement of the study through the village headman.

\section{Recruited prior} to surgery in hospital obesity treatment centre

Mexico and South/Central America Recruitment via flyers in community settings.
30 adults Mean Age 39.1 years. Mean BMI = 47.5 Women 67\% $(n=20)$

Men 33\% $(n=10)$

21 adults

Age range 22 to 81 years.

BMI range 25 - 39

Women $90 \%$ $(n=19)$

Men 10\% $(n=2)$
Six focus groups stratified to gender and ethnicity.

No broad approach specified.
Gender and race/ ethnicity considered; No mention of age, or body size of group facilitators.
Potential recall bias. Sampling and generalisability
Sampling and generalisability
None identified

constant

comparative method informed analysis

Three focus groups

Participants' heights and weights were measured.

\section{No mention of age, gender, or other characteristics}

Sampling and generalisability
Transcripts analyzed by three independent investigators, one of whom was ethnicity concordant.
Ethnicity, language, "Focus groups conducted by a normal weight, bilingual,

Latino investigator and an overweight aide.”
None identified
South East region of USA

Participants recruited from either Weight Watchers or Overeaters Anonymous.
46 participants

Mean age 46.6 years, Mean BMI 33.2 prior

to attempting and

sustaining weight loss 46 individual

Women 78\%

$(n=36)$

Men 22\%

$(n=10)$
Transcript data coded into concepts and themes fitting the theoretical framework explored
No specific mention of gender; age, ethnicity or body size although the researcher/author states she did all the interviews and mentions membership in weight loss organizations.

Interviewer characteristics: researcher participated in the weight loss organizations that she recruited from. "This involvement may have had an influence on 


\section{Continued}

\begin{tabular}{|c|c|c|c|c|c|c|}
\hline $\begin{array}{l}\text { Greener, et al. } 2010 \\
\text { (UK) } \\
\text { To gain an } \\
\text { understanding of } \\
\text { the beliefs of } \\
\text { overweight people } \\
\text { about the causes of } \\
\text { obesity and effective } \\
\text { interventions to } \\
\text { reduce it. }\end{array}$ & $\begin{array}{l}\text { Recruitment of self } \\
\text { identifying overweight } \\
\text { participants from } \\
\text { public places, GP } \\
\text { surgeries, dietetic } \\
\text { services and weight } \\
\text { management groups } \\
\text { Diverse ethnic and } \\
\text { socio-economic } \\
\text { backgrounds }\end{array}$ & $\begin{array}{l}34 \text { men and } \\
\text { women age range } \\
18 \text { - } 50 \text { years. } \\
\text { No details of } \\
\text { gender, mean } \\
\text { age, mean BMI. }\end{array}$ & $\begin{array}{c}\text { Participants self } \\
\text { identified as being } \\
\text { overweight. }\end{array}$ & $\begin{array}{l}\text { Coding and } \\
\text { thematic } \\
\text { analysis with } \\
\text { Framework } \\
\text { Approach }\end{array}$ & $\begin{array}{l}\text { No mention of } \\
\text { gender; age, } \\
\text { ethnicity or } \\
\text { body size } \\
\text { of interviewers. }\end{array}$ & None identified \\
\hline $\begin{array}{c}\text { Heading } 2008 \\
\text { (Australia) } \\
\text { To explore risk } \\
\text { logics, embodiment } \\
\text { and issues related } \\
\text { to adult obesity }\end{array}$ & $\begin{array}{l}\text { Recruitment from } \\
\text { a remote rural } \\
\text { community in } \\
\text { NSW via } \\
\text { newspaper article, } \\
\text { posters, adverts } \\
\text { and presentations }\end{array}$ & $\begin{array}{l}19 \text { participants, } \\
\text { Ages not given } \\
79 \% \text { were } \\
\text { overweight or } \\
\text { obese }(n=15) \\
4 \text { were "normal } \\
\text { weight" but recent } \\
\text { history of obesity } \\
\text { Women } 68 \%(n=13) \\
\text { Men } 32 \%(n=6)\end{array}$ & $\begin{array}{l}19 \text { individual } \\
\text { interviews- } \\
\text { face-to-face } \\
\text { Participants were } \\
\text { "overweight" } \\
\text { "according to } \\
\text { their BMI (and } \\
\text { observation)" }\end{array}$ & $\begin{array}{c}\text { Thematic } \\
\text { inductive } \\
\text { hand coding, } \\
\text { constant } \\
\text { comparative } \\
\text { methods }\end{array}$ & $\begin{array}{l}\text { No mention of } \\
\text { gender; age, } \\
\text { ethnicity or } \\
\text { body size of } \\
\text { interviewers. }\end{array}$ & $\begin{array}{l}\text { Sampling and } \\
\text { generalisability }\end{array}$ \\
\hline $\begin{array}{l}\text { Heintze, et al. } 2011 \\
\text { (Germany) } \\
\text { Patients views for } \\
\text { the future of obesity } \\
\text { management }\end{array}$ & $\begin{array}{l}\text { Recruitment } \\
\text { from solo } \\
\text { general practices } \\
\text { in Germany }\end{array}$ & $\begin{array}{c}15 \text { adults } \\
\text { Mean age } 59 \text { years } \\
\text { Mean BMI = } 32 \\
\text { Women } 73 \%(n=11) \\
\text { Men } 27 \%(n=4)\end{array}$ & $\begin{array}{l}\text { Individual } \\
\text { interviews }\end{array}$ & $\begin{array}{l}\text { Inductive } \\
\text { qualitative } \\
\text { content } \\
\text { analysis. }\end{array}$ & $\begin{array}{l}\text { No mention of } \\
\text { age, ethnicity } \\
\text { of body size } \\
\text { of interviewer }\end{array}$ & $\begin{array}{c}\text { Sampling and } \\
\text { generalisability }\end{array}$ \\
\hline $\begin{array}{l}\text { Herriot, et al. } 2007 \\
\text { (UK) } \\
\text { To gain an insight } \\
\text { into previous dieting } \\
\text { experiences and } \\
\text { current motivators } \\
\text { to individuals } \\
\text { enrolling in the } \\
\text { study at the outset }\end{array}$ & $\begin{array}{l}\text { Recruitment of } \\
\text { participants at the } \\
\text { outset of a trial of } \\
\text { commercial weight } \\
\text { loss programmes }\end{array}$ & $\begin{array}{c}\text { "Baseline sample" } \\
32 \text { adults } \\
\text { Mean age } 42.3 \text { years } \\
\text { Mean BMI = } 32 \\
\text { Women } 78 \% \\
(n=25) \\
\text { Men } 22 \%(n=7) \\
\text { Follow-up sample; } \\
14 \text { adults } \\
\text { Women } 86 \%(n=12) \\
\text { Men } 14 \%(n=2)\end{array}$ & $\begin{array}{l}\text { No mention of } \\
\text { measurement } \\
\text { of BMI }\end{array}$ & $\begin{array}{l}\text { Analyzed } \\
\text { by one } \\
\text { researcher } \\
\text { using “long } \\
\text { table } \\
\text { approach" }\end{array}$ & $\begin{array}{l}\text { Conducted by an } \\
\text { experienced } \\
\text { moderator. } \\
\text { No mention of } \\
\text { gender; age, } \\
\text { ethnicity or } \\
\text { body size of } \\
\text { moderator(s). }\end{array}$ & $\begin{array}{l}\text { Sampling and } \\
\text { generalisability }\end{array}$ \\
\hline $\begin{array}{l}\text { Jones, et al. } 2007 \\
\text { (UK) } \\
\text { To obtain views of } \\
\text { patients attending } \\
\text { community clinics } \\
\text { on the dietetic } \\
\text { service, the outcomes } \\
\text { of dietary treatment } \\
\text { (includes focus on } \\
\text { perceptions of } \\
\text { facilitators } \\
\text { and barriers) }\end{array}$ & $\begin{array}{c}\text { Recruitment of } \\
\text { patients from } \\
\text { primary care } \\
\text { dietetics clinics } \\
\text { in Ayrshire, } \\
\text { West Scotland. } \\
\text { All with BMI > } 28\end{array}$ & $\begin{array}{c}24 \text { participants } \\
58 \%(n=14) \\
\text { over } 50 \text { years. } \\
\text { All with } \\
\text { BMI > 28 } \\
\text { Women } 75 \% \\
(n=18) \\
\text { Men } 25 \%(n=6)\end{array}$ & $\begin{array}{l}24 \text { individual } \\
\text { interviews } \\
\text { (one to one, } \\
\text { mainly in the } \\
\text { patients' homes) }\end{array}$ & $\begin{array}{l}\text { Content } \\
\text { analysis } \\
\text { using } \\
\text { constant } \\
\text { comparative } \\
\text { method }\end{array}$ & $\begin{array}{l}\text { The interviews were } \\
\text { carried out by } \\
\text { researchers from } \\
\text { varied health back } \\
\text { grounds to } \\
\text { determine whether } \\
\text { this influenced the } \\
\text { views expressed } \\
\text { by patients. } \\
\text { No mention of } \\
\text { gender; age, } \\
\text { ethnicity or body } \\
\text { size of interviewers. }\end{array}$ & $\begin{array}{c}\text { Interviewer } \\
\text { characteristics: } \\
\text { "some people } \\
\text { may feel more } \\
\text { comfortable } \\
\text { about pointing } \\
\text { out problems } \\
\text { when the } \\
\text { interviewer is } \\
\text { not a dietitian”. } \\
\text { Sampling and } \\
\text { generalisability }\end{array}$ \\
\hline $\begin{array}{c}\text { Lynch, et al. } 2006 \\
\text { (USA) } \\
\text { To explore obese } \\
\text { African-American } \\
\text { women's } \\
\text { perceptions } \\
\text { regarding barriers } \\
\text { to weight loss and } \\
\text { bariatric surgery }\end{array}$ & $\begin{array}{c}\text { Recruitment of } \\
\text { African American } \\
\text { women via } \\
\text { community } \\
\text { organizations in } \\
\text { Pittsburgh area. Just } \\
\text { over half (51.2\%) } \\
\text { from lowest } \\
\text { income brackets }\end{array}$ & $\begin{array}{c}41 \text { participants } \\
\text { mean age } 48.8 \\
\text { years mean BMI } \\
36.3 \\
\text { Women } 100 \% \\
\quad(n=41)\end{array}$ & $\begin{array}{c}\text { Six focus } \\
\text { groups-self-reported } \\
\text { height and weight to } \\
\text { determine the BMI } \\
\text { of each } \\
\text { individual. }\end{array}$ & $\begin{array}{l}\text { Analysis by } \\
\text { two authors } \\
\text { with open } \\
\text { coding } \\
\text { leading to } \\
\text { identification } \\
\text { of themes }\end{array}$ & $\begin{array}{l}\text { No mention of } \\
\text { gender; age, } \\
\text { ethnicity or } \\
\text { body size of } \\
\text { interviewers. }\end{array}$ & $\begin{array}{c}\text { None } \\
\text { identified }\end{array}$ \\
\hline
\end{tabular}




\section{Continued}

\begin{tabular}{c}
\hline Ogden and Sidhu \\
$\mathbf{2 0 0 6}$ (UK) \\
To examine \\
patients' \\
experiences of \\
taking Orlistat as \\
a means to \\
explore \\
adherence and \\
behaviour change
\end{tabular}

Ogden, et al. 2006 (UK)

To explore patients' experiences of having obesity surgery

\section{Ostberg, et al. 2011} (Sweden)

To explore patients' experiences of a very low calorie diet and influences on weight control

\section{Psarou and Brown 2010 (UK) \\ To explore the views and experiences of obese patients prescribed anti-obesity drugs in primary care, including their understanding of guidance about lifestyle changes}

Sabinsky, et al. 2007 (Denmark) To explore motivation and perceived barriers towards weight

loss among

Danish men

\footnotetext{
Sarlio-Lahteenkorva 1998 (Finland)

To increase understanding of obesity by analysing why permanent weight loss is difficult to achieve
}

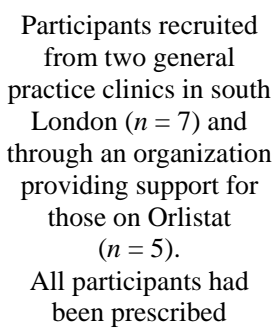

Orlistat in the past year.

All patients $(n=22)$

who had completed

the questionnaire

for a quantitative

cross-sectional study

of the impact of

surgery on health status, were invited

to be interviewed.

Participants recruited from a larger study of low calorie diet

Participants were recruited from three general practices in

Sheffield with

socio-economically diverse populations using purposive sampling

Recruitment of applicants to a weight reduction programme and unskilled workers at a hospital in Copenhagen. Appear to have included less educated groups of men from lower socio-economic backgrounds

Recruitment of applicants to a weight loss trial in Helsinki area of Finland
12 participants mean age 48 years, BMI > 28 to have been prescribed Orlistat Women 58\% $(n=7)$ Men $42 \%(n=5)$

15 participants Mean age of 41 years.

BMI ranges 42 - 58

prior to surgery

Women 93.3\%

$(n=14)$

Men 6.7\%

$(n=1)$

19 participants

Age range

41 - 61 years.

All originally had BMI > 30

Women 78.9\% $(n=15)$

Men 21.1\% $(n=4)$

31 participants mean age 53

All with BMI > 27

All been taking a anti-obesity drug for at least two months within the previous two years.

Women 71\% $(n=22)$ Men 29\% $(n=9)$

13 participants mean age 38.6 years and mean BMI 28.8 Men $100 \%(n=13)$

Four focus groups

1 individual interviews.

ndependent analysis by the authors within

Framework

Approach

Separate inductive analysis by two authors with open coding prescribed

Moderator with "experience in the field" and trained observer.

(Respectively a dentist and secretary!)

No mention of age, gender, body size of

moderators.

No mention of gender; age, ethnicity or body size of interviewers.

NOTE: Project undertaken with the support of two lay team members, each with personal experience of anti-obesity drugs.

No mention of gender; age, ethnicity or body size of focus group facilitators.

Total 90 participants Age range

21 - 66 years Mean BMI 36

Women 83\% $(n=75)$

Men 17\% $(n=15)$
90 individual interviews (face-to-face)
Grounded Theory
No mention of gender; age, ethnicity or body size of interviewer although author names himself, so male gender can be inferred.
Psychological issues might have been better discussed in individual interviews.

Recall bias, since a relatively long period (up to two years) might have elapsed since their experience of initial prescription.

Sampling and generalisability

Sampling and generalisability 


\section{Continued}

\section{Smith, et al. 2012 \\ (Scotland) \\ To describe young \\ adults recollections of adolescent \\ weight awareness and concerns}

Recruited from a cohort who had participated in a study of school children in and around Glasgow

\section{5 participants \\ Age 24 years \\ majority with \\ experience of obesity \\ as adolescent}

Women 54\% $(n=19)$

Men $46 \%(n=16)$
Individual

following semi-structured guide

The study was conducted at a Family Medicine clinic at a southeastern

Thomas, et al. 2008 (USA)

To better understand similarities and differences in

Black and White women's perceptions about obesity
Six focus groups with race-matched facilitators

30 participants

Mean age 48

Mean BMI 41.3

Women $100 \%$

$(n=30)$

Black 57\%

( $n=17)$

White $43 \%$

$(n=13)$ academic medical center.

Physicians referred 69 obese female

potential participants

between the ages of 18 and 70 .

Investigators contacted and screened 56 potential participants (29 Black, 27

White) by telephone for their willingness/ appropriateness for participation in the study. nvestigators

recorded

height, weight

and BMI

prior to focus

group
Framework

Approach to analysis (a)
No details of interviewer(s).
Accuracy of retrospective recall of experiences from about 10 years earlier.
Facilitators were matched according to ethnicity.

There was no mention of gender; age or body size of

focus group facilitators. Investigators

Thematic involved in the analysis theming were from varied educational backgrounds including a clinical psychologist, a master's level psychologist, a family physician and a pharmacologist.
Sampling and generalisability

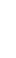

\section{Thomas, et al. 2008 (Australia)}

To explore in detail the extent to which people living with obesity have attempted to lose weight, their attitudes towards dieting and weight loss solutions, their opinions about why their weight loss attempts have failed, and suggestions as to what may help them in their struggle with their weight
Part of a larger study looking at the health and social

experiences of people living with obesity in Victoria,

Australia. Individuals

recruited using articles in

local newspaper, convenience

sampling and at a later stage purposive sampling techniques to diversify the sample.

\section{6 participants}

Mean age 47

years

Mean BMI 42.5,

Women 83\%

$(n=63)$

Men 17\%

$(n=13)$
76 individual interviews either

face to face or by telephone
A constant, continuous, comparative analysis was used
No mention of gender; age, ethnicity or body size of interviewers.

"Interviews were conducted by a team of five experienced qualitative researchers”.
Sampling and generalisability
A brief report about the study was published in a daily newspaper in Victoria,

Thomas, et al. 2008b (Australia)

To develop an in-depth picture of both lived experience of obesity and the impact of socio-cultural factors on people living with obesity
Australia, to recruit a community sample of clinically obese adults.

Community sampling methods were supplemented with purposive sampling techniques to ensure a diverse range of individuals were included.
76 participants

Mean age 47 years $\quad 76$ individual

Mean BMI 42.5,

Women $83 \%$

$(n=63)$

Men $17 \%$

$(n=13)$ either

face to face or

by telephone
As above

gender; age,

ethnicity or

body size of

interviewers. 


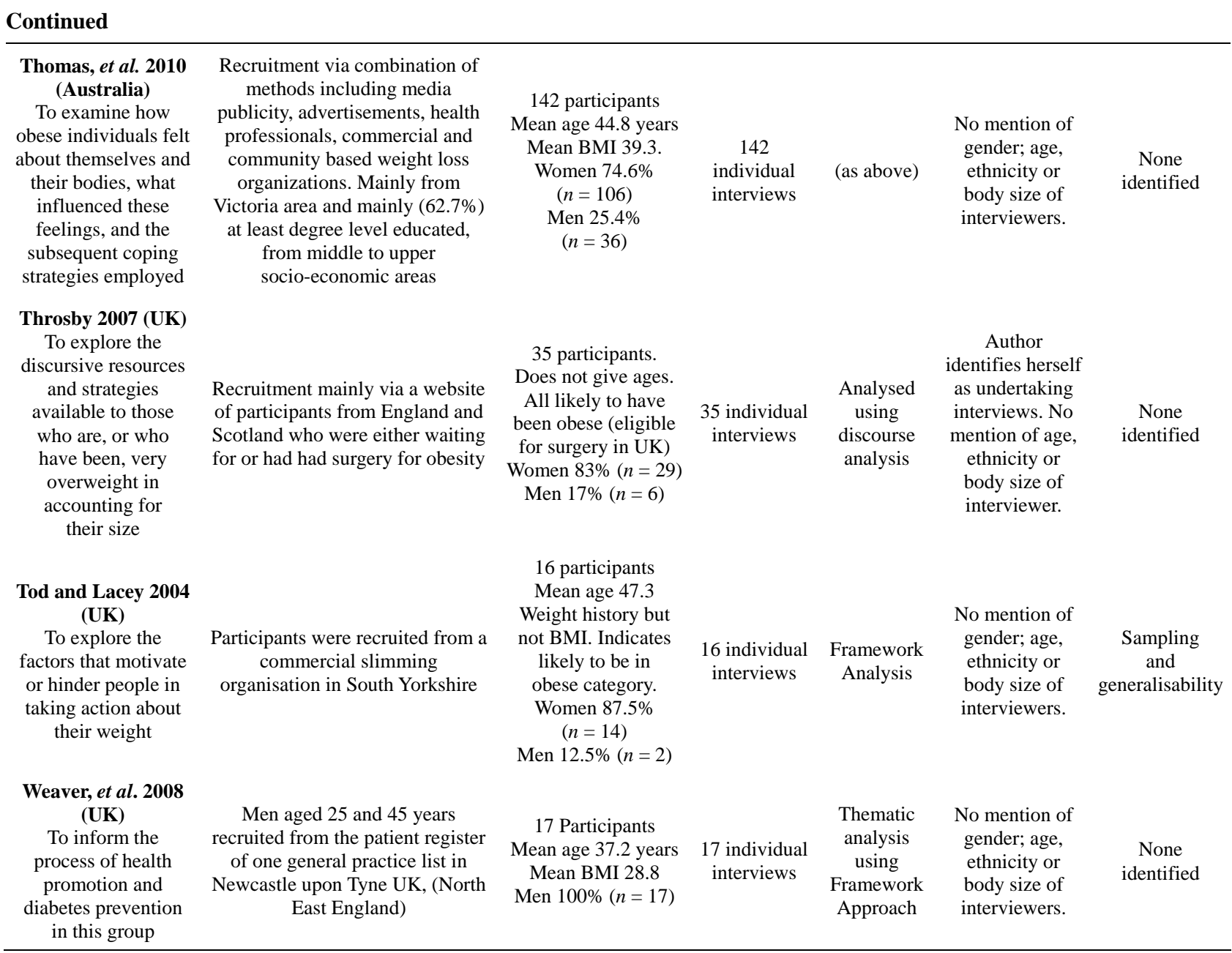

findings. However, in passing, it should be noted that the majority (22 of 31 studies) highlight in their findings, at least to some degree, the influence of obesity stigma on participants' perceptions and experiences.

\subsection{Contexts and Recruitment}

The majority of reports are from authors working in academic institutions in developed countries. Most of the studies are focused on urban populations in these countries. Recruitment settings are divided between community samples (16 studies) and primary health care, outpatient samples and hospital (15 studies). A mix of settings and recruitment strategies is used in the larger studies; some of the community based studies recruited participants active in commercial slimming programs. The sampling setting appears to have been convenience but several studies make a virtue of recruiting either patients or a non-patient community sample in considering the application of findings. Just over half (17) of the studies recruitment contexts are closely linked with interventions to lose weight - study interviews were within a weight management intervention.

\subsection{Participant Characteristics}

Overall 958 different individuals were involved in the studies (1206 participants if including repeat samples of same individuals within different studies). Women (78.8\%) outnumbered men (21.2\%) by a ratio of four to one. The best estimate of the mean age of participants is 44 years (mean age was not reported in all studies). Participants mean BMI could be estimated at $37 \mathrm{~kg} / \mathrm{m}^{2}$ overall; again the mean is not consistently reported. Thirteen studies reported only a BMI range indicating obese participants. The socio-economic background of participants was not reported consistently.

\subsection{Methodological Approach}

Understandably, given space constraints, very few of the reviewed studies reported their methodological approach in any detail but most summarize the approach with reference to established sources. However, in some studies it was difficult to discern any distinct methodological underpinning. Nine studies refer sufficiently to Grounded Theory to be clear that this was the main 
theoretical underpinning. Six other studies also refer to Framework Analysis and others to variants of Thematic and Content analysis. Notwithstanding the scantiness and apparent diversity in methodological underpinnings the actual practice of research was similar across studies. Purposive sampling of convenience populations with face-to-face group or individual interviews employed. Twenty one studies (67.7\%) involved individual in depth interviews; the remaining ten studies (32.3\%) employed focus group methods. Analyses proceeded through multiple stages refining data coding to support inductive analyses.

\subsection{Interviewers and Reflexivity}

All the studies involved participants who would be categorized as medically obese (BMI $30+\mathrm{kg} / \mathrm{m}^{2}$ ). Information on interviewer characteristics was very limited as was discussion of reflexivity. Indeed 22 studies (70.9\%) report nothing about the interviewer characteristics. Nine studies do provide some description, mainly of interviewer occupation, gender and ethnicity where this appears relevant to the groups being interviewed. Only three studies give attention to the body size characteristics of the interviewer. The reports from Chan and Gillick [26] and from Granberg [30] are both vague but indicate the interviewers experienced body weight problems themselves. The report from Diaz, et al. [29] is the only one that is explicit in stating that the focus groups were conducted by one normal weight investigator and one overweight aide.

The limitations discussed within the study reports are very weak as regards researcher reflexivity. Eight studies (25.8\%) did not include any substantive discussion of limitations. The majority (20 studies, 64.5\%) discuss limitations but only in conventional terms for qualitative methods: for example, of potential biases arising from self-selection and convenience sampling, of limits to the generalizability or transferability of findings from a small sample, of potential limitations of group as against individual interviews for acquiring personal views. Only three study reports reflected on how interviewer characteristics could have affected data collection processes and findings. Chan and Gillick [26] and Granberg [30] consider how their own characteristics may have affected recruitment and comfort of participants. Jones and colleagues [35] note that participants may have felt uncomfortable if the interviewer was also a dietician.

\section{DISCUSSION}

\subsection{Review Summary}

As far as possible a comprehensive and systematic approach has been taken in this review of the methodology employed in qualitative studies of adults' experiences of obesity. However, the diverse range and variable quality of studies has necessitated a more exploratory and open review method. A judgment was reached to include studies on the basis that it was clear that most participants were obese and the data were collected by face to face interview. We did not attempt to otherwise weed out weaker studies because we were not concerned with the findings of the studies but with their reported methods. Nevertheless, our review has brought out important issues for qualitative research methods with respect to obesity and allows useful but provisional recommendations to be made about the design and reporting of such studies.

\subsection{Strengths in Reviewed Studies}

The COREQ guidance for assessing quality in research highlights the value of explicit details of the theoretical position and methods [7]. The theoretical framework has consequences for the approach to establishing the quality and rigor of the study. Our review shows that were this to be strictly enforced then nearly a third of studies of obesity would fall short. However, researchers face a challenge within a short article to provide detailed methodological background. There is also the danger of articles reproducing long justifications that belong in epistemology journals rather than health and social research journals. The majority of studies of obesity provide sufficient pragmatic information appropriate to the publication context and most report clearly the study setting, sampling and methods of data collection with attention to quality issues within these methods.

Likewise, on the whole, the reporting of data analysis and interpretation methods is to a good standard. A better consistency in reporting participant characteristics such as socio-economic background, mean ages and BMI is needed and this is further discussed below. Finally, among strengths, the studies present rich data delivering a depth of understanding of the experiences, in their own words, of people living with obesity. Nevertheless, these strengths must be set against limitations in sampling and a stark lack of researcher reflexivity given the focus of the studies.

\subsection{Limitations in Reviewed Methodologies}

Whilst obesity affects all social groups it is important in the context of medical research to consider health inequalities more carefully. Inequalities linked to obesity are complex and shifting [14,51]. There is evidence for social class and ethnicity divisions in the prevalence of obesity and, very clearly, in the health consequences of obesity such as diabetes [51-53]. In common with most clinical studies, the qualitative research about obesity is 
likely to be biased to those who are better off, middle aged, better educated and without the more disabling comorbidities that make participation in research difficult. However, the socio-economic biases in particular are difficult to judge from the reviewed papers and this is an important limitation.

Age and gender are more consistently reported. In most societies, obesity prevalence peaks for both men and women in late middle age; so it is perhaps reasonable that the qualitative research reflects a middle aged perspective. Less justifiable is the bias towards women in a ratio of four to one. Obesity is projected to affect a greater proportion of men than women [12-14,52] and it will be critical to understand the distinct perspective and experiences of men rather than generalize from studies of women.

A further important limitation is the lack of attention to how interviewer characteristics influence data collection. Ironically, even the studies concluding that obesity stigma was a key finding did not attend to its potential impact on their own data collection. The evidence more broadly about stigma and obesity stigma in particular indicates that it is a deep rooted psycho-social phenomenon, not readily under conscious control [15]. Communication skills to establish a good rapport with a participant and to maintain a comfortable and non-judgmental setting are critical in interview methods [54]. Even so, researchers employing face-to-face methods must recognize that people are conscious of obesity stigma and, therefore, the interview interaction presents a heightened challenge as regards management of self and identity. Participants will almost certainly alter their responses to questions as against their perceptions of the size of the interviewer and other influences in the context of the interview. Of course, within a qualitative methodology there is no true or false simple reality-just a greater demand, as in the COREQ criteria, for reflexivity as to the contexts and influences on the data generated.

Within qualitative research telephone interviews have generally been regarded as a weaker method, less able to provide rich data than face-to-face interviews [55]. However, this general tenet appears to be based on assumptions about how people traditionally behaved using telephones rather than empirical evidence. Where telephone interviews have been employed (particularly with harder to reach groups and where a degree of social stigma may be present within face-to-face work) the reports of data quality are positive, and this includes studies of obesity [56-59]. The advantages of telephone interviews are worth reiterating. First, it potentially makes the study more accessible to participants reluctant to arrange a face-to-face interview; this may include men. Second, it removes the effects of the body size of the interviewer from influencing the data. Telephone interviews have potential, therefore, and might be considered in study design as an alternative to face-to-face methods. However, the evidence of advantages and disadvantages is still limited with respect to obesity.

\subsection{Conclusion}

Methodologically pragmatic studies are improving understanding of the experience of obesity. The studies are of variable quality and the impact of obesity stigma, a deep rooted psycho-social phenomenon in most societies, has not been attended to in the methodology of these studies. The implications for qualitative research of obesity stigma are therefore unclear. Researchers should consider the sampling biases in previous studies, particularly with a view to involving more men. Clearer information about study participants, including socio-economic background, would be helpful. Studies involving face-to-face interviews should report on salient interviewer characteristics including body size. In time, this will provide a clearer picture of how these characteristics might affect data collection and study findings.

\section{ACKNOWLEDGEMENTS}

This study was in receipt of funding from the Collaborations for Leadership in Applied Health Research and Care for South Yorkshire (CLAHRC SY). CLAHRC SY acknowledges funding from the National Institute for Health Research (NIHR). The views and opinions expressed are those of the authors, and not necessarily those of the NHS, the NIHR or the Department of Health.

\section{REFERENCES}

[1] Boulton, M. and Fitzpatrick, R. (1994) Qualitative methods for assessing health care. Quality in Health Care, 3, 107-113. doi:10.1136/qshc.3.2.107

[2] Murphy, E. Dingwall, R. Greatbatch, D. Parker, S. and Watson, P. (1998) Qualitative methods in health technology assessment: A review of the literature. Health Technol Assess, 2, Monograph.

[3] The PLoS Medicine Editors. (2007) Qualitative research: Understanding patients' needs and experiences. PLoS Medicine, 4, 1283-1284.

[4] Neergaard, M. Olesen, F. Andersen, R.A. and Sondergaard, J. (2009) Qualitative description-The poor cousin of health research? BMC Medical Research Methodology, 9, 52-57. doi:10.1186/1471-2288-9-52

[5] Mays, N. and Pope, C. (2000) Assessing quality in quailtative research. British Medical Journal, 320, 50-52. doi:10.1136/bmj.320.7226.50

[6] Malterud, K. (2001) Qualitative research: Standards, challenges, and guidelines. Lancet, 358, 483-488. doi:10.1016/S0140-6736(01)05627-6

[7] Tong, A, Sainsbury, P. and Craig, J. (2007) Consolidated criteria for reporting qualitative research (COREQ): A 
32-item checklist for interviews and focus groups. International Journal for Quality in Health Care, 19, 349-357. doi:10.1093/intqhc/mzm042

[8] Pound, P. Britten, N. Morgan, M. Yardley, L. Pope, C. and Daker-White, G. (2005) Resisting medicines: A synthesis of qualitative studies of medicine taking. Social Science \& Medicine, 61, 133-155. doi:10.1016/j.socscimed.2004.11.063

[9] Brown, I. and Gould, G. (2011) Decisions about weight management: A synthesis of qualitative studies of obesity. Clinical Obesity, 1, 99-109. doi:10.1111/j.1758-8111.2011.00020.x

[10] Green, J. and Thorogood, N. (2009) Qualitative methods for health research. Sage, London.

[11] Ritchie, J. and Lewis, J. (2003) Qualitative research practice. Sage, London.

[12] TOS Obesity as a Disease Writing Group. (2008) Obesity as a disease. Obesity, 16,161-177.

[13] World Health Organization. (2000) Obesity: Preventing and Managing the Global Epidemic. WHO, Geneva.

[14] Foresight. (2007) Tackling obesities: Future choices. Government Office for Science, London.

[15] Brownell, K. Puhl, R. Schwartz, M. and Rudd, L. (2005) Weight bias: Nature, consequences and remedies. Guilford Press, New York.

[16] Puhl, R. Heuer, C. (2009) The stigma of obesity: A review and update. Obesity, 17, 941-964. doi:10.1038/oby.2008.636

[17] De Brun, C. and Pearce-Smith, N. (2009) Searching skills toolkit: Finding the evidence. Wiley-Blackwell BMJ Books, Chichester.

[18] Thomas, J. and Harden, A. (2007) Methods for the thematic synthesis of qualitative research in systematic reviews. ESRC National Centre for Research Methods, London.

[19] PHRU. (2006) Critical appraisal skills programme. Public Health Resource Unit, England. www.phru.nhs.uk

[20] Ali, H. Baynouna, L. and Bernsen, R. (2010) Barriers and facilitators of weight management: Perspectives of Arab women at risk for type 2 diabetes. Health and Social Care in the Community, 18, 219-228. doi:10.1111/j.1365-2524.2009.00896.x

[21] Befort, C.A., Thomas, J.L., Daley, C.M., Rhode, P.C. and Ahluwalia, J.S. (2008) Perceptions and beliefs about body size, weight, and weight loss among obese AfricanAmerican women: A qualitative inquiry. Health Education \& Behavior, 35, 410-426. doi:10.1177/1090198106290398

[22] Blixen, C. Singh, A. and Thacker, H. (2006) Values and beliefs about obesity and weight reduction among African-American and Caucasian women. Journal of Transcultural Nursing, 17, 290-297. doi:10.1177/1043659606288375

[23] Brown, I. Thompson, J. Jones, G. and Tod, A. (2006) Obesity, stigma and quality of life. International Journal of Interdisciplinary Social Sciences, 1, 169-178.

[24] Brown, I. Thompson, J. Tod, A. and Jones, G. (2006)
Primary care support for tackling obesity: A qualitative study of the perceptions of obese patients. British Journal of General Practice, 56, 666-672.

[25] Byrne, S. Cooper, Z. and Fairburn, C. (2003) Weight maintenance and relapse in obesity: A qualitative study. International Journal of Obesity and Related Metabolic Disorders, 27, 955-962. doi:10.1038/sj.ijo.0802305

[26] Chan, N. and Gillick, A. (2009) Fatness as a disability: Questions of personal and group identity. Disability \& Society, 24, 231-243. doi:10.1080/09687590802652520

[27] Chang, C.T. Chang, K.H. and Cheah, W.L. (2009) Adults' perceptions of being overweight or obese: A focus group study. Asia Pacific Journal of Clinical Nutrition, 18, 257 264.

[28] Da Silva, S. and Costa Maia, A. (2012) Obesity and treatment meanings in bariatric surgery candidates: A qualitative study. Obesity Surgery, 22, 1714-1722. doi:10.1007/s11695-012-0716-y

[29] Diaz, V., Mainous, I. and Pope, C. (2007) Cultural conflicts in the weight loss experience of overweight Latinos. International Journal of Obesity, 31, 328-333. doi:10.1038/sj.ijo.0803387

[30] Granberg, E. (2006) "Is that all there is?” Possible selves, self-change, and weight loss. Social Psychology Quarterly, 69, 109-126. doi:10.1177/019027250606900201

[31] Greener, J. Douglas, F. and Van Teijlingen, E. (2010) More of the same? Conflicting perspectives of obesity causation and intervention amongst overweight people, health professionals and policy makers. Social Science \& Medicine, 70, 1042-1049. doi:10.1016/j.socscimed.2009.11.017

[32] Heading, G. (2008) Rural obesity, healthy weight and perceptions of risk: Struggles, strategies and motivation for change. Australian Journal of Rural Health, 16, 86-91. doi:10.1111/j.1440-1584.2008.00961.x

[33] Heintze, C. Sonntag, S. Brinck, A. Huppertz, M. Niewohner, J. Wiesner, J. and Braun, V. (2012) A qualitative study on patients' and physicians' visions for the future management of overweight and obesity. Family Practice, 29, 103-109. doi:10.1093/fampra/cmr051

[34] Herriot, A.M. Thomas, D.E. Hart, K.H. Warren, J. and Truby, H. (2008) A qualitative investigation of individuals' experiences and expectations before and after completing a trial of commercial weight loss programmes. Journal of Human Nutrition and Dietetics, 21, 72-80. doi:10.1111/j.1365-277X.2007.00837.x

[35] Jones, N. Furlanetto, D. Jackson, A. and Kinn, S. (2007) An investigation of obese adults' views of the outcomes of dietary treatment. Journal of Human Nutrition and Dietetics, 20, 486-494. doi:10.1111/j.1365-277X.2007.00810.x

[36] Lynch, C., Chang, J., Ford, A. and Ibrahim, S. (2007) Obese African-American women's perspectives on weight loss and bariatric surgery. Journal of General Internal Medicine, 22, 908-914.

doi:10.1007/s11606-007-0218-0 
[37] Ogden, J., Clementi, C. and Aylwin, S. (2006) The impact of obesity surgery and the paradox of control: A qualitative study. Psychology \& Health, 21, 273-293. doi:10.1080/14768320500129064

[38] Ogden, J. and Sidhu, S. (2006) Adherence, behavior change, and visualization: A qualitative study of the experiences of taking an obesity medication. Journal of Psychosomatic Research, 61, 545-552. doi:10.1016/j.jpsychores.2006.04.017

[39] Ostberg, A., Wikstrand, I. and Bostrom, K. (2011) Group treatment of obesity in primary care practice: A qualitative study of patients' perspectives. Scandinavian Journal of Public Health, 39, 98-105. doi:10.1177/1403494810391524

[40] Psarou, A. and Brown, I. (2010) Patients' experiences of prescribed anti-obesity drugs and perceptions of support from primary care: A qualitative study. Primary Health Care Research \& Development, 11, 250-259. doi:10.1017/S1463423610000083

[41] Sabinsky, M., Toft, U., Raben, A. and Holm, L. (2007) Overweight men's motivations and perceived barriers towards weight loss. European Journal of Clinical Nutrition, 61, 526-531.

[42] Sarlio-Lahteenkorva, S. (1998) Relapse stories in obesity. European Journal of Public Health, 8, 203-209. doi:10.1093/eurpub/8.3.203

[43] Smith, E., Sweeting, H. and Wright, C. (2012) 'Do I Care?' Young adults' recalled experiences of early adolescent overweight and obesity: A qualitative study. International Journal of Obesity, 37, 303-308. doi:10.1038/ijo.2012.40

[44] Thomas, A.M., Moseley, G., Stallings, R., Nichols-English, G. and Wagner, P.J. (2008) Perceptions of obesity: Black and white differences. Journal of Cultural Diversity, 15, 174-180.

[45] Thomas, S.L., Hyde, J., Karunaratne, A., Herbert, D. and Komesaroff, P.A. (2008) Being 'fat' in today's world: A qualitative study of the lived experiences of people with obesity in Australia. Health Expectations, 11, 321-330. doi:10.1111/j.1369-7625.2008.00490.x

[46] Thomas, S.L., Hyde, J., Karunaratne, A., Kausman, R. and Komesaroff, P.A. (2008) "They all work...when you stick to them": A qualitative investigation of dieting, weight loss, and physical exercise, in obese individuals. Nutrition Journal, 7, 34-44. doi:10.1186/1475-2891-7-34

[47] Thomas, S., Karunaratne, A., Lewis, S., Castle, D., Knoesen, N. and Honigman, R. (2010) 'Just bloody fat!' A qualitative study of body image, self-esteem and coping in obese adults. International Journal of Mental Health Promotion, 12, 39-49.

\section{doi:10.1080/14623730.2010.9721805}

[48] Throsby, K. (2007) 'How could you let yourself get like that?': Stories of the origins of obesity in accounts of weight loss surgery. Social Science \& Medicine, 65, 1561-1571. doi:10.1016/j.socscimed.2007.06.005

[49] Tod, A. and Lacey, A. (2004) Overweight and obesity: Helping clients to take action. British Journal of Community Nursing, 9, 59-66.

[50] Weaver, N.F., Hayes, L., Unwin, N.C. and Murtagh, M.J. (2008) "Obesity" and “clinical obesity" men's understandings of obesity and its relation to the risk of diabetes: A qualitative study. BMC Public Health, 8, 311-320. doi:10.1186/1471-2458-8-311

[51] McLaren, L. (2007) Socioeconomic status and obesity. Epidemiologic Reviews, 29, 29-48. doi:10.1093/epirev/mxm001

[52] Devaux, M. and Sassi, F. (2012) Social inequalities in obesity and overweight in 11 OECD countries. European Journal of Public Health, 23, 464-469. doi:10.1093/eurpub/ckr058

[53] Stringhini, S., Tabak, A., Akbaraly, T., Sabia, S., Shipley, M., et al. (2012) Contribution of modifiable risk factors to social inequalities in type 2 diabetes: Prospective Whitehall II cohort study. British Medical Journal, 345, e5452. doi:10.1136/bmj.e5452

[54] King, N. and Horrocks, C. (2010) Interviews in qualitative research. Sage, London.

[55] Chapple, A. (1999) Issues in research. The use of telephone interviewing for qualitative research. Nurse Researcher, 6, 85-93.

[56] Burke, L. and Miller, M. (2001) Phone interviewing as a means of data collection: Lessons learned and practical recommendations. Forum: Qualitative Social Research, 2, 7.

[57] Novick, G. (2008) Is there a bias against telephone interviews in qualitative research? Research in Nursing \& Health, 31, 391-398. doi:10.1002/nur.20259

[58] Lewis, S., Thomas, S.L., Blood, R.W., Hyde, J., Castle, D.J. and Komesaroff, P.A. (2010) Do health beliefs and behaviors differ according to severity of obesity? A qualitative study of Australian adults. International Journal of Environmental Research and Public Health, 7, 443-459. doi:10.3390/ijerph7020443

[59] Lewis, S., Thomas, S.L., Hyde, J., Castle, D., Blood, R.W. and Komesaroff, P.A. (2010) "I don't eat a hamburger and large chips every day!” A qualitative study of the impact of public health messages about obesity on obese adults. BMC Public Health, 10, 309-320. doi:10.1186/1471-2458-10-309 